研究

練乳に対する酸化防止剤 BHA の防腐性について

梶本五郎*・遠藤義臣**

体位向上に乳製品の必要性はいうまでもなく，近年ま すむすその摄取量は增加している。ところが牛乳および 乳製品は閣敗しやすく，長く保存することは困難であ る。さきに著者ら ${ }^{(1) 31}$ は脂肪の酸化防止绪が，抗菌性， 抗カビ性および防虫性を有することを報告し，各食品に 添加し，その防腐効果を推めてきた。今回，酸化防止绪 のうち, butyl hydroxy anisole (BHA) を練乳添加 し，防腐性定試験した結果，0.01〜0.001\%添加内で防 痛勃果を示したので，その結果を報告する。

\section{1. 試料书よび試料の調製}

無糖練乳（ネッスル日本株式会社製）を選び，それで れ 0.1\% BHA アルコール溶液を $0.001 \%, 0.005 \%$ お よび $0.01 \%$ になるよう練乳に添加し，よく㩭挥後， 65 ${ }^{\circ} \mathrm{C}$ で 30 分間オートクレーブ中で加熱しのち, $200 \mathrm{ml}$ ピーカーに $100 \mathrm{~m} l$ ずつ秤取し， $25^{\circ} \mathrm{C}$ の室温にて放置し た。な，酸化防止剂の BHAには，2つの異性体があ り, サステンは 3-tert-butyl-4-hydroxyanisole が約93 $\sim 94 \%$, 2-tert-butyl-4-hydroxyanisole $\not 3$ 約 $6 \sim 7 \%$ の混合物である。<smiles>COc1ccc(O)c(C(C)(C)C)c1</smiles>

(3-異性体)<smiles>COc1ccc(O)cc1C(C)(C)C</smiles>

(2-異性体)
2. 実験方法

1) 乳酸の定量

放置した練乳の一定量 $(10 \mathrm{~g})$ をとり, 乳酸量を求め た。

2) 凝 固 性

それぞれの放置練乳を $0.2 \mathrm{ml}$ ずつとり， $80^{\circ} \mathrm{C}$ の温慂 中に滴下し，混合後の凝固性を観察した。

3）揮発性塩基性窒量の定量
放置練乳を $10 \mathrm{~g} す ゙ つ と り ， 50 \mathrm{ml}$ の蒸溜水を加え， 鄮拌しながら 30 分間浸出操作崖行ない，ついで $20 \%$ $\mathrm{HClO}_{4}$ 液 $10 \mathrm{~m} l$ 学加光よく混和し，10 分間放置したの 古沪過し，残查物を $20 \% \mathrm{HClO}_{4}$ および蒸溜水で洗淡 し，100 $\mathrm{ml}$ にしたのについて吸収方法 (1000 ml min)により求め，乾澡重量に対す百分率で表わした。

4) レダクターゼ試験

放置練乳を共栓付き三角フラスコに $10 \mathrm{~g}$ ずっとり， $0.5 \mathrm{ml}$ のメチレンブルー液 (メチレンブルーのアルコ 一ル飽和溶液 $5 \mathrm{~m} l$ に水 $195 \mathrm{~m} l$ 加え混合した溶液） 加えて $50^{\circ} \mathrm{C} て ゙ 24$ 時間放置後の色調学観察した。なお BHA はメチレンブルーを還元しなかった。また 3)，4） の試験試料は $25^{\circ} \mathrm{C} ， 60$ 時間放置したものである。

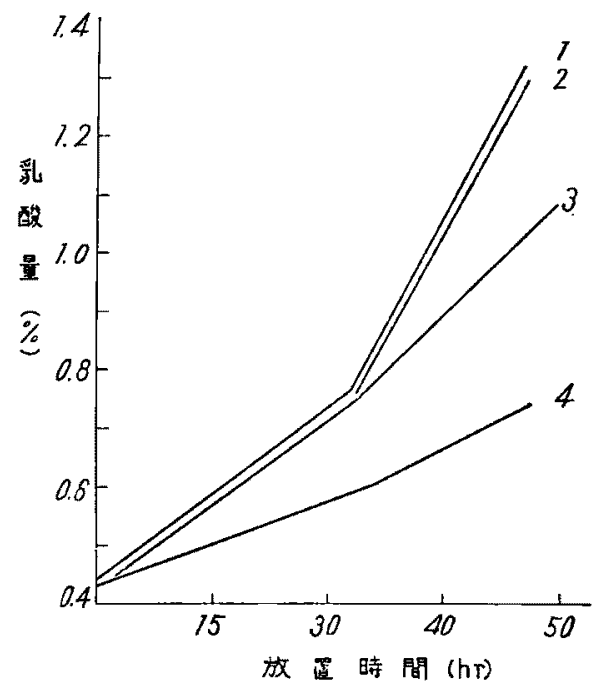

1. 無添加練乳 $2.0 .001 \%$ 添加練乳

3. $0.005 \%$ 添加練乳 4. $0.01 \%$ 添加練乳 第 1 図 BHA 添加練乳の放置時間と乳酸 量について

* 神戸森女子短期大学（神户市兵庫区会下山 1 )

** 日本㨂発油株式会社（東京都干代田区大手町 2-4)

On the Applicability of Antiseptic Action of Antioxidant BHA to Condensed Milk. By GoRoH Kajimoto and YosHiomı ENDō. 
第 1 表 BHA 添加練乳の放置時間と凝固性に วWて

\begin{tabular}{|c|c|c|c|c|c|c|c|}
\hline BHA 添加濃度 $(\%)$ & 10 & 20 & 35 & 50 & 70 & 90 & 100 \\
\hline 無＼cjkstart添 & - & - & + & + & + & + & + \\
\hline $0.001 \%$ 添 加 & - & - & + & + & + & + & + \\
\hline $0.005 \%$ 添 加 & - & - & - & - & + & + & + \\
\hline $0.01 \%$ 添 加 & - & - & - & - & - & + & + \\
\hline
\end{tabular}

第 2 表 BHA 添加練乳の 揮発性塩基性窒素量 およびメチレンブルー還元性について

\begin{tabular}{|c|c|c|c|c|}
\hline BHA 添加量 & 然添加 & $0.001 \%$ & $0.005 \%$ & \\
\hline $\begin{array}{c}\text { 揮発性塩基性咥素 } \\
\text { (mg \%) }\end{array}$ & & 520 & 48.6 & \\
\hline $\begin{array}{l}\text { メチレンブル } \\
\text { 垔元 性比較 }\end{array}$ & 淡緑色 & 緑 & 緑 色 & \\
\hline
\end{tabular}

\section{3. 実験結果および考察}

練乳に添加した酸化防止靔 BHAの防腐性を謂ベるた め，まず放置時間と乳酸量を比較した。その結果注第 1 図のとおりである。

BHA 添加練乳は無添加練乳にくらべ乳酸量は少な く，その比呇は添加量が多いはど乳酸量は少なかった。

一般に告乳および練乳の新鮮度の比較に乳酸の定量も 行なわれ，乳酸量の多いほど新鮮度が低いとみなされて いる。したがって BHAを添加することにより，練乳の 新鮮度を保持させることができると思われるので，さら にこの点を確加めるため, 凝固性, 揮発性塩基性窒素お よびレダクターゼ試験安行なった。それらの結果は第 1 〜2表のとおりである。なお㠜固性試験で凝固したもの を十，凝固しないものをーとして記した。

無添加練乳と BHA の $0.001 \%$ 添加練乳はとも飞35洔 間放置で凝固し， $0.005 \%$ 添加練乳は 70 時間で凝固し， $0.01 \%$ 添加練乳では 90 侍間放置で凝固した。

揮発性塩基性窒素量は無添加練乳がもっとも多く， BHA の派加量が多くなるにしたがい少なかった。みチ
レンブルーの還元性の比較は舆添加練乳がもっとも色調 薄く，すなるち細菌が多いと考えられる。

以上のように練乳に BHA を添加することにより，釈 酸および揮発性塩基性公素量が少なく，凝固性を拈くら すことから，それだけに練乳が衛生的であり，かつ保存 性を增するのである。ただし BHA の $0.001 \%$ 添加で は，以ずれの試駼においてもるずかに防腐放果認める 程度で， $0.005 〜 0.01 \%$ 添加が望をしいと思う。またこ の範囲の BHA 濃度では毒性のないことを確めだ。

\section{4. 要約}

然糖練乳に油脂の酸化防止剂である BHA 它それぞれ $0.001 \%, 0.005 \%, 0.01 \%$ ずつ添加し，65 C で 30 分間 加熱後, $200 \mathrm{~m} l$ のビーカーに $100 \mathrm{~m} l$ ずつ秤取し, $25^{\circ} \mathrm{C}$ の室温に放置しながら，放置時間と乳酸量，凝固性，揮 発性塩基性空菜およびメチレンブルーの還元性の比較試 験を行なった。

(1) BHA を添加した練乳の乳酸量は 無涯加にくらべ 少なく，その比菜は BHA 添加量が多いほど少なかっ t。

（2）BHA 添加練孚しの凝固性は無添加練乳と $0.001 \%$ BHA 添加練乳は 35 時間放置で凝固し，0.005\% 添加練 乳では 70 時間で凝固し，0.01\%添加練乳では 90 時間で 凝固した。

（3） BHA 添加練乳の揮発性塩基性䁷素量を求める と，無添加練乳で $58 \mathrm{mg} \% ， 0.001 \%$ BHA 添加練乳て $52 \mathrm{mg} \%, \quad 0.005 \%$ BHA 添加練乳で $48 \mathrm{mg} \%, \quad 0.01 \%$ BHA 添加練㔀で $28.6 \mathrm{mg} \%$ であった。

(4) メチレンプルーの䢬元性を比較すると無添加練乳 がもっとも早く還元された。

\section{文献}

1）３）捤本五郎・笠村贵美子・遠藤義臣：栄䓹と食 糧, 14，(5)，371，378，384 (1962)

4）梶本五郎：栄瑟と食糧，14，(3)，170(1961). (1961 年10月 27 日受理) 